\title{
Awards for Achieving Athletes to Increase Welfare
}

\author{
Reza Ryanantama Cristi*, Komarudin Komarudin, Nuryadi Nuryadi \\ Department of Education, School of Postgraduate Studies \\ Universitas Pendidikan Indonesia \\ Bandung, Indonesia \\ *Rezaryanantama5@gmail.com
}

\begin{abstract}
The background in this study is to see the awarding of athletes who are performing. This study aims to see how the implementation of awarding both athletes and coaches in terms of financial and non-financial. This research method is a descriptive study, the population in this study athletes and coaches of Jambi Province who participated in the PON XIX 2016. The sampling technique used was purposive sampling totaling 59 athletes and 13 trainers. Analysis of the data used in this study in the form of percentage data and correlation. The results of this study indicate that financial and non-financial rewards for outstanding athletes in the award category run quite well. Furthermore, financial awards for award-winning trainers run quite well, while non-financial awards in the award category run well.
\end{abstract}

Keywords—financial; non financial; well being

\section{INTRODUCTION}

A public policy as a program that is projected with certain goals, certain values and certain practices [1]. The policy regarding the sports system issued by each government is usually not in accordance with what is expected, how should the local government implement a sports policy that applies and must comply with the existing law. The government, sports coaches, and all components of society need to seek breakthroughs and solutions related to the provision of welfare guarantees for athletes, coaches and sportsmen to be more motivated to achieve. Therefore, the parties from the government themselves need to carry out this award in accordance with the laws and regulations that are available to all sports players, sports organizations, government or private institutions, and individuals who excel or contribute in promoting sports are rewarded. In order for every athlete, coach, sportsman and all who gain achievements and merit in advancing sports obtain their life welfare, so there are no more cases of athletes who are not prosperous.

From all the descriptions and findings of the problem, researchers are interested in conducting research on "Awards for outstanding athletes to improve the welfare of PON XIX athletes in 2016 Jambi Province."

\section{METHOD}

\section{A. Participans}

In determining the population, the author refers to the opinion of Fraenkel et al. [2] "The population, in other words, is the group of interest to the researcher, the group to whom the researcher would like to generalize the results of the study." The population in this study was all athletes and trainers Jambi Province that participated in the 2016 PON XIX. The sports that followed by Jambi Province in the 2016 PON XIX event totaled 28 sports. The 28 sports are Paddle, Wrestling, Table Tennis, Wushu, Karate, Weightlifting, Drum band, Judo, Weight lifting, Roller shoes, Archery, Tarung drajat, Pentaque, Bicycle racing, Gymnastics, Pencak silat, Basketball, Bridge, Boxing, Taekwondo, Water Polo, Rock Climbing, Athletics, Swimming and Billiards. With a number of contingent athletes and coaches 215 people. Considerations to be taken as a sample of this study are athletes and trainers from 14 sports who received medals at the 2016 PON XIX with a total of 72 people consisting of 59 athletes and 14 coaches. The research sample was only limited to athletes and coaches who received medals at the 2016 PON XIX, with criteria for athletes and coaches who achieved both gold, silver and bronze medals.

\section{B. Instrument}

In this study the authors adopted a system of reward instruments for athletes and coaches and the welfare of athletes and coaches with the aim of seeing the implementation carried out by the government in giving awards to outstanding athletes and coaches, what financial and non-financial awards provided by Jmabi Province and how the impact on the welfare of athletes and trainers in Jambi Provinis. The concept of reward was adopted from the book Human Resources Management in Sport and Recreation, written by Chelladurai and Kerwin [3].

\section{DISCUSSION}

\section{A. Implementation of Award Giving to Achieving Athletes in Jambi Province}

Based on the highest percentage value, it can be concluded that the awarding of achievement athletes in Jambi Province is included in the award category running quite well with a percentage of $57.79 \%$, based on the athlete's point of view. Whereas from the trainer's point of view, awarding achievement athletes in Jambi Province was included in the award category running quite well with a percentage of $56.93 \%$. In the implementation of awarding, it runs according to the existing regulations, but many are financial in nature, but regarding the work and the house of the Jambi Provincial Government cannot realize it 
The results of interviews with athletes say that the awarding has not been able to impact their welfare. While the interviewer with the trainer said that they currently have a coach who has been given a job and some have not got a job. Explained by Bana and Shitindi some workers are highly motivated by extrinsic rewards such as salary increases, promotions and bonuses, other workers are motivated by intrinsic rewards such as appreciation, praise, and recognition [4]. Thus it can be said that appreciation is very important for a worker, as well as athletes who really need an award so that they can motivate them to continue achieving.

The reward system is very beneficial for athletes to continue to excel, because one of the goals of awarding is to appreciate the efforts of an athlete in achievement. The athletes who have good national and international levels must be appreciated by the government, the role and success of an athlete is from the coach, even the coach behind the success of the athletes, therefore the role of the coach should not be forgotten and must be rewarded according to the success of the athletes. Even though it has been mentioned in Law Number 3 of 2005 concerning the National Sports System, that every Provincial and City Government in Indonesia must pay attention to the welfare of athletes or those who have become former athletes. Several studies have shown appreciation for having a positive impact on workplace health and safety [5]. Appreciation is a motivation that must be continually improved by every athlete, the obligation of the government that gives the award must come to those who are entitled to receive it. The government is required to think and find a way out so that athletes feel cared for, not athletes are charged with high achievement but there is no reciprocity. If there is no incentive from the government, someone will think again, even unable to focus on being an athlete. During this time, the government was only able to promise bonuses for medalists and coach athletes. Furthermore, incentives from the government are still minimal. Explained by Probst and Brubaker, which concludes that the difference between job satisfaction and dissatisfaction lies in the number and type of awards given or given to employees and the number and type of awards that employees are expected to deserve [6].

\section{B. Financial Award Given by the Jambi Provincial Government to Achieving Athletes}

Based on the highest percentage value, it can be concluded that, financial awards for achievement athletes in Jambi Province fall into the category "awards run quite well with a percentage of $48.44 \%$ seen from the perspective of athletes, then the awarding of financial achievement athletes in Jambi Province is in the category" awards run quite well with a percentage of $50.35 \%$ seen from the trainer's point of view. The results of interviews of several athletes at the moment are the awards received in the form of incentives and bonuses, so that it is part of the financial award, which is said to be sufficient by some athletes with a nominal value given by the government. However, there are some athletes who say that the nominal award or incentive has not been able to meet their needs, because there are several athletes who already have a family, and that can have an impact on the welfare of the athletes.
Awards are compensation received by employees from organizations to exchange services offered by employees or as compensation for work performed, in other words that awards are rewards that must be given by superiors to subordinates, this is the same as an accomplished athlete who must be rewarded as reward for their achievements. Extrinsic rewards are external to work assignments, including salary, working conditions, benefits, security, and promotion, service contracts, salaries, incentives, bonuses, payment and security of work environment and working conditions [7].

Financial awards given by the Jambi Provincial Government are only in the form of nominal bonuses and incentive monthly or the amount of incentives and bonuses according to the achievements they achieve in giving bonuses and incentives, even if the athlete does not receive it, it will be subject to income tax. Incentives in organizations such as salaries, must be clear including giving awards, recognition, promotions, bonuses and the work environment [5]. It can be said that the provision of incentives to athletes and trainers must be given accordingly and precisely, because that is a reward for the sweat of their toil while struggling and training hard for achievement.

\section{Non Financial Award Given by the Jambi Provincial Government to Achieving Athletes}

Based on the highest percentage value, it can be concluded that non-financial awards for achievement athletes in Jambi Province fall into the category of good enough, with a percentage of $57.20 \%$ seen from the athlete's point of view, then awarding non-financial achievement athletes in Jambi Province in the category went well, with a percentage of $64 \%$ seen from the trainer's point of view. The results of interviews with athletes that the provision of non-financial awards provided by the government do not yet exist, even to get a job not given but only limited to being recommended to work in an agency or in a company. In Jambi Province, there are several athletes who have found work as civil service police units. In this case, they only get jobs, no one has got a house or anything else. In 2017 there was indeed an award or an appreciation to former athletes who were awarded with a sum of money as a rope of love and were given title awards as outstanding athletes who had brought the fragrant name of Jambi Province.

It can be concluded that if the non-financial awards given by the government to athletes and trainers are fulfilled, the achievements will be even better. As previously explained, non-financial awards can be felt by athletes and coaches both directly and indirectly in accordance with the performance of the athlete and the trainer itself. If athletes and coaches have good performance, athletes and coaches will be satisfied with the non-financial awards provided by the company. Conversely, if athletes and coaches do not have good performance, the non-financial awards provided by the government cannot be used optimally.

\section{Impact of Giving Award to the Prosperity of Achieving Athletes in Jambi Province}

Judging from the athlete's point of view of the data between financial well-being obtained a value of 0.893 if referring to the 
correlation coefficient table above the value of person correlation with a range of $0.70-0.89$ then between welfare and financial have a very strong relationship. Whereas when referring to the data correlation coefficient table between welfare and non-financial value of person correlation with a range of $0.10-0.29$ then between welfare and non-financial has a weak relationship.

Viewed from the point of view of the trainer of data between financial well-being obtained a value of 0.952 if referring to the table of correlation coefficients above the value of person correlation with a range of $>0.90$ then between welfare and financial have a near perfect relationship. Then when viewed from the data between financial welfare obtained a value of 0.595 when referring to the correlation coefficient table above the value of person correlation with a range of 0.50 - 0.69 then between welfare and non-financial have a strong relationship.

Welfare is a measuring point for a society that has been in a state of prosperity. Such prosperity can be measured from health, economic conditions, happiness and quality of life of the people [8]. It can be said that this well-being is realized so that these citizens can live decent lives and are able to develop themselves, so that they can carry out their social functions properly, if a prosperous society means that the community experiences prosperity, therefore athletes and coaches who have struggled must think about their welfare.

\section{E. Impact of Giving Award to the Prosperity of Achieving Athletes in Jambi Province}

Judging from the athlete's point of view of the data between financial well-being obtained a value of 0.893 if referring to the correlation coefficient table above the value of person correlation with a range of $0.70-0.89$ then between welfare and financial have a very strong relationship. Whereas when referring to the data correlation coefficient table between welfare and non-financial value of person correlation with a range of $0.10-0.29$ then between welfare and non-financial has a weak relationship.

Viewed from the point of view of the trainer of data between financial well-being obtained a value of 0.952 if referring to the table of correlation coefficients above the value of person correlation with a range of $>0.90$ then between welfare and financial have a near perfect relationship. Then when viewed from the data between financial welfare obtained a value of 0.595 when referring to the correlation coefficient table above the value of person correlation with a range of 0.50 - 0.69 then between welfare and non-financial have a strong relationship.

Welfare is a measuring point for a society that has been in a state of prosperity. Such prosperity can be measured from health, economic conditions, happiness and quality of life of the people [8]. It can be said that this well-being is realized so that these citizens can live decent lives and are able to develop themselves, so that they can carry out their social functions properly, if a prosperous society means that the community experiences prosperity, therefore athletes and coaches who have struggled must think about their welfare.

\section{CONCLUSIONS}

Based on the results of data analysis, description of the results of the study, and discussion, it can be concluded, that the awarding of outstanding athletes to improve the welfare of athletes in Jambi Province based on financial rewards for outstanding athletes in the award category runs quite well, while awarding non-financial athletes with high achievement in the award category runs pretty well. Furthermore, the awarding of financial rewards for award-winning trainers runs quite well, while non-financial awards in the award category run well.

Then viewed from the point of view of the athlete the impact of awarding financial with well-being has a very strong relationship, while the appreciation of non-financial with welfare has a weak relationship. Furthermore, in the view of the trainer regarding awarding financials with well-being, the relationship is near perfect, while the appreciation of nonfinancial with welfare has a strong relationship. Athletes who are married will need non-financial rewards because if the athlete has got a decent job the athlete will feel more prosperous. Whereas athletes who are not yet married will take advantage of financial rewards because they have not thought of other needs.

\section{REFERENCES}

[1] B. Nugroho, Aplikasi pemrograman web dinamis dengan PHP dan MySQL. Gava Media, Yogyakarta, 2004.

[2] J.R. Fraenkel, How to design and evaluate research in education, New York: McGraw-Hill Humanities/Social Sciences/Languages, 2012.

[3] P. Cheladurai and S. Kerwin, Human Resource Management in Sport and Recreation. third edition United Kingdom, 2017.

[4] B. Bana and E. Shitindi, Performance Management in the Tanzania Public Service. Conference on Governance Excellence: Managing Human Potential 2nd - 4th March, 2009

[5] J.N. Kikoito, Impact of Reward Systems on the Organizations Performance in Tanzanian Banking Industry: A Case of Commercial Banks in Mwanza City (Doctoral dissertation, The Open University of Tanzania), 2014.

[6] T.M. Probst and T.L. Brubaker, "The effects of job insecurity on employee safety outcomes: Cross-sectional and longitudinal explorations," Journal of occupational health psychology, vol. 6, no. 2, pp. 139, 2001.

[7] S.R. Badrinarayan and P. Tilekar, "Critical Analysis of Motivators and Hygiene Factors with special reference to employes of Private and Public sector Banks in India," Internasioanl Journal of Research in IT \& Management, vol. 1, no. 1, pp. 39-50, 2011.

[8] E. Segel and S. Bruzy, Social Welfare Policy, Program, and Practice. Itasca IL: Peacock, 1998. 